\title{
The Abuse of Presidential Power of Pardon and the Need for Restraints
}

\author{
Imo Udofa \\ Faculty of Law, University of Uyo, Uyo, Nigeria \\ Email: imoudofa@gmail.com
}

How to cite this paper: Udofa, I. (2018). The Abuse of Presidential Power of Pardon and the Need for Restraints. Beijing LaW Review, 9, 113-131.

https://doi.org/10.4236/blr.2018.92008

Received: February 10, 2018

Accepted: April 25, 2018

Published: April 28, 2018

Copyright (C) 2018 by author and Scientific Research Publishing Inc. This work is licensed under the Creative Commons Attribution International License (CC BY 4.0).

http://creativecommons.org/licenses/by/4.0/

\begin{abstract}
This paper examined the nature and application of presidential power of pardon in Nigeria, the United States of America, India and South Africa, amongst others. The power of pardon is an important component of executive powers, which allows the President to intervene and grant pardon, as a way of "dispensing the mercy of government" in exceptional cases where the legal system fails to deliver a morally or politically acceptable result. It exists to protect citizens against possible miscarriage of justice, occasioned by wrongful conviction or excessive punishment. Nevertheless, in recent times, this power has, in practice, become a personal prerogative of the President, a remnant of tribal kingship generally reserved for the well-heeled or well connected. The power of pardon is virtually unfettered and unchecked by formal constraints in most jurisdictions, thereby rendering it susceptible to abuse. However, in some jurisdiction there are conventionally specified criteria which guide the grant of pardon. The paper also examined some of the incidents of abuse of presidential power of pardon in Nigeria and other jurisdictions and proffered suggestions aimed at ensuring a more purposeful and beneficial exercise of the pardon power, particularly in Nigeria.
\end{abstract}

\section{Keywords}

Power of Pardon, Abuse, Nigeria, America, India, Restraints

\section{Introduction}

The recent exercise of presidential power of pardon by the current American President, Donald Trump, by granting pardon to Joe Arpaio has rekindled the 
discussion on the uses and abuses of the pardon power. ${ }^{1}$ Arpaio, a former sheriff of Maricopa County, Arizona, was found guilty in July 2017 of criminal contempt for defying a judge's order against prolonging traffic patrols targeting immigrants. The exercise of pardon power by Donald Trump in favour of Arpaio has been widely criticised as an abused of power. It has been argued that Arpaio should have been allowed to serve his punishment and the presidential pardon amounted to a presidential endorsement of the criminal contempt for which Arpaio was punished.

In Nigeria there have been several instances of presidential pardon. ${ }^{2}$ While some of the cases were adjudged to be fair and deserving, ${ }^{3}$ others were criticised and described as a display of executive high-handedness and abuse of power. ${ }^{4}$ However, the pardon by President Goodluck Jonathan of Chief D.S.P. Alamieyesigha, former Governor of Bayelsa State, convicted of several corruption charges, remains the most controversial exercise of presidential pardon power in the country. ${ }^{5}$

In strict constitutional jurisprudence, the exercise of pardon power amounts to an interference by the executive with the exercise of judicial power; in breach of the sacred doctrine of separation of powers. ${ }^{6}$ However, such interference would be allowed when authorised by the same Constitution that provided for

${ }^{1}$ M. Waldman, "Trumps Pardon of Joe Arpiao is Unpardonable", N.Y. Daily News, Saturday, Auguest 26, 2017 available online at http://www.nydailynews.com/opinon/trumps-pardon. Accessed December 28, 2017, see also J. Chong, "The Arpiao Pardon Dangerously Accelerates Trump's Assault on the Rule of Law" The New Yorker, August 27, 2017 available at

http://www.newyorker.com/news-desk/the-arpiao-pardon. Accessed 15/12/2017. Note also the Pardon of former Peruvian President, Fujimori, who was sentenced to six years imprisonment for bribery and abuse of power see "Peru's Jailed Former Authoritarian Leader Fujimori Gets Medical Pardon" VOA News, December 27, 2017 available at

http://www.voanews.com/a/peru-jailed-former-. Accessed 2/1/2018.

${ }^{2}$ See V.M. Mpamugoh, "Exercise of Prerogative of Mercy: Dr. Obi Okongwu's Pardon Visited", (1988) 2 Calabar Law Journal 45-46; S.A.M. Ekwenze, "Presidential Pardon and Prerogative of Mercy: A Necessary National Soothing Balm for Social Justice", available at http://coou.eduing/nesources/presidential-pardon-and-prerogative-of-mercy. Accessed 5/2/2018.

${ }^{3}$ For example, General Yakubu Gowon's pardon of Chief Obafemi Awolowo, convicted of treasonable offences; President Shagari's pardon of General Yakubu Gowon, accused of involvement in a coup plot that overthrew the regime of General Murtala Mohammed; General Babangida's pardon of Nduka Irabor and Tunde Thompson, two journalists jailed under the obnoxious Decree N0. 4; General Abubakar's pardon of General Obasanjo, convicted of involvement in a coup plot.

${ }^{4}$ President Obasanjo's pardon of the then Speaker of House of Representatives, Nigeria, Salisu Buhari, convicted of certificate forgery; President Goodluck Johnathan's pardon of D.S.P. Alamieyeseigha, convicted of several financial crimes and Mr. Shetima, former Managing Director of Bank of the North, convicted of official corruption and misappropriation of Bank funds. See generally F. Agbedo, "Presidential Pardon under the Constitution" The Nation online March 19, 2013, available at http://thenationaonline.net/presidential-pardon-under-. Accessed 5/2/2018.

${ }^{5}$ See Agbedo, Ibid (stressing that public outrage and controversy foreshadowing the above pardon granted to corrupt politicians, calls to question the governments sincerity in its avowed determination to truly tackle the menace of corruption in the country, as the survival of the people including the government itself depends on stamping out this systemic scorge in our body politic).

${ }^{6}$ See J. Locke, Second Treaties of Civil Government, Chapters 12-13, B.O. Iluyomade and B.U. Eka, Cases and Materials on Administrative Law in Nigeria (1980) pp. 1-2. See F. Ogoloma, "The Theory of Separation of Powers in Nigeria: An Assessment" (2001) 6(3) African Research Review 26,128 . 
the doctrine of separation of powers. Presidential pardons are by design, a check upon the occasional excesses and misjudgments of the judiciary. ${ }^{7}$

The presidential pardon power is an important component of executive powers, and it allows the President to intervene and grant pardon as a way of "dispensing the mercy of government" in exceptional cases where the legal system fails to deliver a morally or politically acceptable result. ${ }^{8}$ It exists to protect citizens against possible miscarriage of justice, occasioned by wrongful conviction and excessive punishment or where, in the interest of social and political stability and peaceful co-existence, it is necessary to show mercy. Nevertheless, it appears that in recent times, this power has, in practice, become a personal prerogative of the President, a remnant of tribal kingship generally reserved for the well-heeled or well-connected (Love, 2007).

The exercise of presidential pardon power has, in recent times, come under severe attack in Nigeria and other jurisdictions, where the power has been abused by Presidents who have allowed personal and parochial considerations to dictate their decisions. This paper sets out to examine the nature and purpose of the pardon power. Cases of abuse of this power in Nigeria and other jurisdictions and the existing measures for prevention of such abuse of pardon power are also examined; and suggestions aimed at ensuring a more purposeful and beneficial exercise of the pardon power, particularly in Nigeria, are proffered.

\section{Meaning and Origin of Pardon}

The Black's Law Dictionary (Garner, 2009) defines the word "pardon", as "the act or an instance of officially nullifying punishment or other legal consequences of a crime. A pardon is usually granted by the Chief Executive of a government such as the President in respect of federal offences and the Governor in respect of State offences. ${ }^{9}$

In $U S \boldsymbol{V}$ Wilson, ${ }^{10}$ Chief Justice Marshall defined a pardon as:

$\ldots$ an act of grace, proceeding from the power entrusted with the executive of laws, which exempts the individual, on whom it is bestowed, from the punishment the law inflicts for a crime he has committed. It is the private, though official act of the executive magistrate delivered to the individual for whose benefit it is intended and not communicated officially to the court.

However, in Biddle $\boldsymbol{v}$ Perovich, Holmes J. declared that:

A pardon in our days is not a private act of grace from an individual happening to possess power. It is part of the constitutional scheme. When

${ }^{7}$ See F.O. Bowman, "Dean Chemerinsky, Separation of Powers, and the Arpiao Pardon" available at http://impeahableoffences.net/2017/09/01/dean. Accessed 2/1/2018.

${ }^{8}$ See A. Hamilton, The Federalist 74 at 422 (maintaining that, "the Criminal Code of every country partakes so much of necessary security that without an easy access to exceptions in favour of unfortunate guilt, justice would wear a countenance too sanguinary and cruel").

${ }^{9}$ Ibid.

${ }^{10} 32$ US (1933) USSC 33, (7 pet) 150 (1833) at 160 Approved by the Supreme Court in Burdick v United States (1915) USSC 134, 236 US 79, 89 (1915). 
granted it is the determination of the ultimate authority that the public welfare will be better served by inflecting less than what the judgment fixed.

Thus, in Nigeria, the power to pardon, which is described as the prerogative of mercy, is a constitutional power vested in the President to exercise in respect of federal offences ${ }^{11}$ and in the Governor of a State, in respect of State offences. ${ }^{12}$ However, its origin is of great antiquity. The pardon power was borrowed from Britain, where it was part of the royal prerogative. According to Blackstone:

By the word prerogative we usually understand that special pre-eminence which the King hath, over and above all other persons, and out of the ordinary course of the common law, in right of his regal dignity. It signifies in its etymology, something that is required or demanded before, or in preference to all others. ${ }^{13}$

Hood-Philips and Jackson highlight the peculiar characteristic of the royal prerogative and its relation to the common law as follows:

The essential characteristic of the royal prerogative, then, is that it is unique and pre-eminent. It is not 'out of the ordinary course of the common law' in the sense of being above the law; it is part of the common law, but an exception to the principles that apply to citizens generally. (Hood-Philips \& Jackson, 2001)

In his insightful contribution, Dicey describes the royal prerogative as the residue of discretionary or arbitrary authority, which at any given time, is left in the hands of the Crown (Dicey, 1959). The use of the word arbitrary in this context does not make the royal prerogative to be seen as powers above the law but as being confined according to the best usage of the common law as distinct from statutory powers. ${ }^{14}$

At the present, the royal prerogative has survived in various areas. There is the prerogative which touches on the person of the monarch; under which the monarch is immune from legal actions and is also unaffected by any statute unless so expressly provided. In the legislative area, the monarch has a prerogative to summon, prorogue and dissolve Parliament and also assent to legislation. In the executive sphere, the monarch's prerogative includes the right to appoint and dismiss Ministers, civil servants and officers and men of the Armed Forces. Technically, the monarch is the head of the Armed Forces. In times of national emergency, the Crown is responsible for defence of the realm and is the sole judge of the existence of danger from external aggression. ${ }^{15}$ In the judicial arena, the monarch is the "fountain of justice" and all criminal prosecutions are held in his name. Of particular importance in the judicial sphere is that the monarch possesses the prerogative of mercy by which persons concerned with or con-

${ }^{11}$ Constitution of the Federal Republic of Nigeria (CFRN), 1999, s. 175.

${ }^{12}$ Ibid. at s. 212.

${ }^{13}$ Blackstone, Commentaries 1, 239.

${ }^{14}$ Hood Philips and Jackson, Op. Cit. at 305.

${ }^{15}$ See R. V. Hampden (1637) 3 State, $\left.\operatorname{Tr} \& 26\right)$ quoted in Mpamugoh, Op. Cit 45-46. 
victed of crimes may be pardoned or reprieved by royal command, through the office of the Home Secretary in Britain. ${ }^{16}$

Historically, "a pardon was ...a work of mercy, whereby the king, either before attainder, sentence, or conviction, or after, forgiveth any crime, offence, punishment, execution, right, title, debt, or duty, temporal or ecclesiastical". ${ }^{17}$ The power was absolute, unfettered and not subject to any judicial scrutiny (Coke, 1669). It was used to entrench regimes by "endearing the sovereign to his subjects" (Blackstone, 1769). The aspect of the British royal prerogative, called the prerogative of mercy, has become part of Nigerian law; and since independence, successive Nigerian Constitutions have made provisions for the exercise of the prerogative of mercy. ${ }^{18}$

\section{Pardon and Amnesty}

The Black's Law Dictionary defines Amnesty as a pardon extended by the government to a group or class of persons usually for political offence; the act of a sovereign power officially forgiving certain classes of persons who are subject to trial but have not yet being convicted..$^{19}$ Unlike an ordinary pardon, amnesty is usually addressed to crimes against State sovereignty; that is, to political offences with respect to which forgiveness is deemed more expedient for the public welfare than prosecution and punishment. Amnesty is usually general, addressed to classes or even communities-also termed general pardon. ${ }^{20}$

Amnesty allows the government of a nation or State to "forget" criminal acts, usually before prosecution has occurred. Amnesty has traditionally been used as a political tool of compromise and reunion following a war. An act of amnesty is generally granted to a group of people who have committed crimes against the State, such as treason, rebellion, or desertion from the military. ${ }^{21}$

From the foregoing, it can be firmly established that an amnesty is a form or specie of pardon which is usually granted to a group or class of persons. ${ }^{22}$

\section{Power to Pardon under the Nigerian Constitution}

Under the Constitution of Nigeria, 1999, section 175 which deals with the exer-

${ }^{16}$ See generally, Mpamugoh, Ibid.

${ }^{17}$ Per Wayne J. in Exparte Wells, 59 US (18 How) 307, 311 (1855).

${ }^{18}$ CFRN, 1960, ss. 94-96; CFRN, 1963, s. 101; CFRN, 1979, s. 161. See also E.S. Olarinde, "Cuurent Trends in Granting Pardon in United Kingdom, United States of America and Nigeria" available at http://www.academia.edu/10338732/CURRENT_TREND_IN_GRANTING_PARDON_IN accessed $15 / 2 / 2018$.

${ }^{19}$ Garner, Op. Cit. at 99.

${ }^{20}$ Ibid. The Yar'Adua Administration in Nigeria, granted amnesty to the armed militant groups that operated in the Niger-Delta region, destroying oil pipelines and other installations, kidnapping expatriate oil workers, and generally demanding control of oil resources in the region. Since there is no express legal framework on amnesty in Nigeria, the grant of amnesty to the said armed militant groups was based on the provisions of section 175 of the Constitution of Nigeria, dealing with prerogative of mercy.

${ }^{21}$ Garner, Op. Cit.

${ }^{22}$ For detailed analysis of the relationship between Pardon and Amnesty, see E. Azinge, "The Concept of Amnesty and its Place in Human Rights Discourse" Being a Paper Presented at the Nigerian Bar Association $53^{\text {rd }}$ Annual General Conference held at Tinapa Calabar, Nigeria, 27 $7^{\text {th }}$ August 2013. 
cise of prerogative of mercy by the President, provides as follows:

Section 175(1) The President may-

1) Grant any person concerned with or convicted of any offence created by an Act of the National Assembly a pardon, either free or subject to lawful conditions;

2) Grant to any person a respite, either for an indefinite or for a specified period, of the execution of any punishment imposed on that person for such an offence;

3) Substitute a less severe form of punishment for any punishment imposed on that person for such an offence; or

4) Remit the whole or any part of any punishment imposed on that person for such an offence or of any penalty or forfeiture otherwise due to the State on account of such an offence.

5) The powers of the President under subsection (1) of this section shall be exercised by him after consultation with the Council of State.

6) The President, acting in accordance with the advice of the Council of State, may exercise his powers under subsection (1) of this section in relation to persons concerned with offences against the army, naval or air force law or sentenced by a court marital.

The above constitutional provisions confer extensive powers of prerogative of mercy on the President in relation to federal offences. Similar powers are also conferred on State Governors, in relation to State offences. ${ }^{23}$

It is significant to note that the power of the Chief Justice of the Federation and the Chief Judge of the respective States in Nigeria to order the release of prison inmates is not derived from the pardon power enshrined in section 175 of the Constitution, but from the Police $\mathrm{Act}^{24}$ and the Criminal Justice (Release from Custody) (Special Provisions) Act. ${ }^{25}$ Indeed, the prisoners so released by the Chief Judges are not pardoned but merely released from illegal prison custody. ${ }^{26}$ To that extent, they may be re-arrested and prosecuted by the government. $^{27}$

Under section 175(1) of the Constitution of Nigeria, 1999, the President may grant a pardon either free or subject to lawful conditions, to any person convicted of or concern with an offence under any Act of the National Assembly, or may grant a respite to any person either for an indefinite period or for a specific period, from the execution of any punishment. The President may also substitute a lesser form of punishment for an imposed punishment or remit any penalty or forfeiture. The expression "concerned with or convicted of" used in sec${ }^{23}$ CFRN, 1999, s. 212.

${ }^{24}$ Cap P29 LFN, 2010, s. 11.

${ }^{25}$ LFN, 2010, s. 1(1). See also the case of Iloegbunam v Iloegbunam (2001) 47 WRN 72 G.A. where the Court of Appeal in Nigeria, upheld the constitutional validity of the Criminal Justice Release from Custody (Special Provisions) Act. See also Administration of Criminal Justice Act, 2015, s. 8. ${ }^{26}$ See "Judicial Recognition of Chief Judges Power to Release Prisoners by Femi Falena", Sahara Reporters, September 4, 2017.

${ }^{27}$ Ibid. 
tion 175(1) (a) of the Constitution implies that free or conditional pardon may be granted to a person who is still on trial or who has been arrested in connection with the offence but has not yet been tried or has been convicted though punishment is not yet imposed..$^{28}$ In the American case of Murphy $v$ Ford ${ }^{29}$ the plaintiff claimed that President Ford's pardon of Nixon could not be validly granted to a person who had never been indicted or convicted and who had therefore never been formally charged with an offence against the United States. The Michigan District Court reiterated the pardon power's unlimited application by citing the majority opinion in Garland's case, ${ }^{30}$ thus: "It extends to every offence known to law, and may be exercised at any time after its commission, either before legal proceedings are taken, or during their pendency, or after conviction and judgment".

By section 175(3) of the Constitution of Nigeria, the President's prerogative of mercy extends to persons concerned with offences against the army, naval, or air force law or convicted or sentenced by a court martial. The power of the President to grant pardon under section 175(1) of the Constitution shall be exercised by him after consultation with the Council of State. ${ }^{31}$ This provision imposes a peremptory obligation on the President to consult. Therefore, any grant of pardon by the President without consultation with the Council of State is unconstitutional and void (Nwabueze, 1982).

However, the President is under no obligation to accept and act upon the advice given during the consultation. On the other hand, by section 175(3) of the Constitution, the President is required to exercise his power of prerogative of mercy, acting on the advice of the Council of State. Clearly, the President is bound by the advice of the Council of State under this subsection, since he is expressly mandated to act on the advice of that body.

In Nigeria, the power of prerogative of mercy has been exercised at both Federal and State levels at various times. A few examples will suffice: it the Federal level, General Yakubu Gowon, as Head of State, granted pardon to Chief Obafemi Awolowo and Chief Anthony Enahoro who had been convicted of offences of treason and treasonable felony and sentenced to lengthy jail terms. ${ }^{32}$ President Shehu Shagari granted pardon to Chief Emeka Ojukwu and Dr. Yakubu Gowon, without any trial, for various offences against the State. ${ }^{33}$ General ${ }^{28}$ See Okongwu v State (1986) 5 NWLR (Pt. 44) 721.

${ }^{29} 390 \mathrm{~F}$ Supp 1372 (WD Michigan 1975).

${ }^{30} 71$ US 333 (1866).

${ }^{31}$ CFRN, 1999, s. $175(2)$.

${ }^{32}$ Mpamugoh, Op. Cit. at 45-46. In America, President Bill Clinton pardoned millionaire Mare Rich after Rich had been indicted in 1983 on charges of racketeering and mail and wire fraud arising out of his oil business. President Gerald Ford also pardoned former President Richard Nixon over his involvement in the Watergate scandal. Recently, President Donald Trump pardoned Joe Arpaio, the former Sheriff of Maricopa County, Ariz, who was found guilty of criminal contempt for defying a judge's order against prolonging traffic patrols targeting immigrants.

${ }^{33}$ See Daily Times of February 17, 1983 at 3. Nwabueze argues that in the case of the untried offender, the exercise of prerogative of mercy appears pre-emptive of the court process and consequently encroaches upon the judicial powers, which is a violation of the separation of powers doctrine. See B.O. Nwabueze, Constitutional Law of the Nigerian Republic (1964) p. 296. 
Abdulsalami Abubakar pardoned Chief Olusegun Obasanjo in 1999 shortly before the general elections of that year. Obasanjo was convicted of an alleged coup plot in 1995 and sentenced to life imprisonment by a military tribunal. President Goodluck Jonathan granted pardon to DSP Alamieyeseigha and others who were convicted of various corruption offences. ${ }^{34}$

At the State level, the power to pardon or grant prerogative of mercy has been variously exercised by State Governors. Thus, Governor Adekunle Ajasin of Ondo State exercised his power to pardon in favour of persons alleged to be his party members who had been convicted of arson..$^{35}$ At about the same time, Chief Bola Ige, as Governor of Oyo State, pardoned Eniola Atanda who was jailed for committing an offence. ${ }^{36}$ Dr. Obi Okongwu was granted pardon after due consultation with the Anambra State Advisory Council on the Prerogative of Mercy, having been convicted of contempt of court and sentenced to 21 days imprisonment; some of which he had served. ${ }^{37}$

It is settled that, in Nigeria, the pardon power is not subject to judicial review. The power of the President or Governor to pardon is absolute and unfettered and therefore susceptible to abuse. Indeed, the Supreme Court of America, in Ex-parte Garland, ${ }^{38}$ stated the position in America, which is similar to that of Nigeria, thus, "The pardon power of the President is not subject to legislative control, Congress can neither limit the effect of his pardon or exclude from its exercise any class of offenders. The benign prerogative of mercy reposed in him, cannot be fettered by any legislative restrictions".

However, the courts in Nigeria have held that a pardon cannot be properly granted to a person whose appeal against conviction is pending in the appellate court. Thus, in Obidike $\boldsymbol{v}$ State, ${ }^{39}$ the Court of Appeal failed to accord recognition to the pardon granted to the appellant while his appeal was pending. The court therefore dismissed the appeal and ordered that the appellant be re-arrested and executed in accordance with the judgment of the trial court. However, in Isibor $\boldsymbol{v}$ State, ${ }^{40}$ the Supreme Court did not order the re-arrest and execution of the appellant who had been granted a pardon while his appeal was pending. After dismissing the appellant's appeal, the Supreme Court, per Ejiwunmi, JSC, stated as follows:

It is clear that the appellant from the above has been made a free man by the fiat of the Head of State (and) commander-in-chief of the Armed Forces-General Abdul Salami Abubakar on the $5^{\text {th }}$ March 1999. However, having regard to the verdict of this court in this Appeal, it does now appear that the appellant cannot be punished as provided by law in respect of the

\footnotetext{
${ }^{34}$ See M. Atebor, "Jonathan Confirms Pardon for Alamieyeseigha, says "Owe no one Apology", Premium Times, March 13, 2013.

${ }^{35}$ See Daily Times, February 17, 1983 at 3. Also quoted in Mpamugoh, Op. Cit.

${ }^{36}$ Mpamugoh, Op. Cit. at 48.

${ }^{37}$ Ibid.

${ }^{38} 71$ US 333 (1866)

${ }^{39}$ (2001) 17 NWLR (Pt 743) 601 CA.

${ }^{40}$ (2002) FWLR (Pt. 98) 843.
} 
offence for which he stands convicted. It is hoped that deliberate effort would be made in the future to avoid situations of this kind when exercises of this nature are carried out.

Clearly, the approach adopted by the Court of Appeal in Obidike's case was harsh and confrontational; while the approach adopted by the Supreme Court in Isibor's case was consistent with democratic ideals and is therefore, preferable.

\section{The Legal Effect of Pardon}

In $E_{\boldsymbol{X}}$-Parte Garland $^{41}$ the legal effect of pardon was stated as follows:

The inquiry arises as to the effect of a pardon, and on this point the authorities concur. A pardon reaches both the punishment prescribed for the offence and the guilt of the offender, and when the pardon is full; it releases the punishment and blots out of existence the guilt, so that in the eye of the law the offender is as innocent as if he had never committed the offence. If granted before conviction, it prevents any of the penalties and disabilities, and restores him to all his rights. It makes him, as it were a new man, and gives him new credit and capacity. There is only this limitation to its operation; it does not restore offices forfeited, or property or interests vested in others in consequence of the conviction and sentence.

In that case, an Act of the United States of 1865 prescribed an oath that a deponent should swear that he had never borne arms against the United States as a qualification for admission or call to the American bar on pains of conviction for perjury and deprivation from holding any office or place in the United States for life. Garland had held office in the confederate army which had rebelled against the Federal Government during the American civil war. He was pardoned by President Andrew Johnson. He sought from court by petition permission to practice his legal profession without taking the oath required by the Act of 1865 which he was unable to take by reason of the office he had held in the confederate army. He rested his case on two planks, namely, that the Act of 1865 was unconstitutional and void, and that he had been released from compliance by the pardon.

The same legal effect would appear to be the conclusion of the English courts. Thus, in Hay $\boldsymbol{v}$ Justices of the Tower Division of London, ${ }^{42}$ the plaintiff was convicted of an offence but was pardoned by the Queen. He then applied for a licence to sell spirits by retail. The law then was that persons convicted were forever disqualified from being granted a licence to sell spirit by retail. The court held that:

When the crime of which a man has been convicted is pardoned, he is absolved not only from the punishment inflicted upon him by the judge who

\footnotetext{
${ }^{41} 71$ U.S. 333 (1866).
}

${ }^{42}(1890) 23$ QBD, 561. 
pronounced sentence, but from all penal consequences, such as disqualification from following his occupation. To treat it otherwise would be contrary to all good sense. ${ }^{43}$

Similarly, in Cuddington $\boldsymbol{V}$ Williams, ${ }^{44}$ the plaintiff brought an action against the defendant for calling him a thief. The plaintiff had earlier been granted pardon for the offence. The court held that though he had been convicted of the offence, yet when the pardon came, it had cleared the person of the crime and infamy.

The Nigerian courts follow the English and American courts on the legal effect of a pardon. Thus, in Falae $v$ Obasanjo, ${ }^{45}$ the Court of Appeal also held that a pardon cleared the person pardoned of both the crime and the infamy. In that case the petitioner, Chief Olu Falae brought a petition against the respondent, Chief Olusegun Obsanjo, then President-elect of Nigeria, on the ground that the respondent was not eligible to contest the 1999 election having been convicted by a military tribunal. The respondent had been pardoned by General Abdulsalami Abubakar before he contested the election. The Court of Appeal held in favour of the respondent that by virtue of the pardon granted him by the then Head of State, he was eligible to contest the election.

Musdapher, JCA, said:

In my view, under Nigerian law there is no distinction between "pardon" and "a full pardon." A pardon is an act of grace by the appropriate authority which mitigates or obliterates the punishment the law demands for the offence and restores the rights and the privileges on account of the offence. The effect of a pardon is to make the offender a new man, or novus homo, to acquit him of all corporal penalties and forfeitures annexed to the offence pardoned.

Any title, property, or monies earlier forfeited on account of the offence, are as a general rule, usually restored forthwith to the person who is pardoned. Except where the pardon is not full, or the property can no longer be specifically restored, due to the fact that the property has legally vested in other persons, in which case monetary compensation is usually paid to the person pardoned to enable him recover his loses, otherwise, all monies and properties earlier forfeited, or abandoned are usually restored in kind and in full to the person pardoned. ${ }^{46}$

In the earlier case of Okongwu $\boldsymbol{V}$ State, ${ }^{47}$ the court held that the effect of a free pardon is such as to remove from the subject of the pardon, "all pain, penalties and punishments whatsoever that from the said conviction may ensure, but not

${ }^{45} 71$ U.S. 333 (1866) Ibid. at 567.

${ }^{46}(1615) 80$ ER 216.

${ }^{45}$ (1999) 4 NWLR (Pt. 599) 476.

${ }^{46}$ Gov. of Lagos State v Ojukwu (1986) 1 NWLR (Pt. 18) 621 SC. See also Ogualaji v A.G. Rivers State (1997) 6 NWLR (Pt. 508) 209 Okeke v Oruth (1999) 6 NWLR (Pt. 606) 175.

${ }^{47}$ (1986) 5 NWLR (Pt. 44) 721. 
to wipe out the conviction itself" ${ }^{48}$ Thus, the conviction will still be in the court's record even though the penalties have been nullified. Accordingly, a person who has been granted a pardon can still appeal against his conviction. ${ }^{49}$

\section{Justifications for the Pardon Power}

In Ex-parte Phillip Grossman Case, ${ }^{50}$ Chief Justice Taft made a classical exposition of the justifications for the pardon power within the legal system, when he stated as follow:

Executive clemency exists to afford relief from undue harshness or evident mistake in the operation or enforcement of the criminal law. The administration of justice by the courts is not necessarily always wise or certainly considerate of circumstances which may properly mitigate guilt. To afford a remedy, it has always been thought essential in popular governments, as well as in monarchies, to vest in some other authority than the courts power to ameliorate or avoid particular judgments.

The most important justifications for the pardon power which could be gleaned from the above exposition include the following:

\section{1) Remedying the Injustice Done by the Judiciary}

The judiciary, like any other institution, is not infallible. Judges can make mistakes and the Constitution has to have a safety valve, that allows for injustice to be remedied. Thus, the pardon power may be exercised in favour of a person who may have been wrongly convicted. On the other hand, a person may be rightly convicted, yet the punishment may appear to be excessive and disproportionate or there may be extenuating circumstances that justify lowering the sentence.

Arguing in favour of the pardon power, Alexander Hamilton, ${ }^{51}$ posited that, "humanity and good policy" require that the benign prerogative of pardoning was necessary to mitigate the harsh justice of the Criminal Code. The pardon power could provide for "exceptions in favour of unfortunate guilt". He continued, "The Criminal Code of every country partakes so much of necessary severity, that without an easy access to exceptions in favour of unfortunate guilt, justice would wear a countenance too sanguinary and cruel". To this end, the pardon power acts as an important check and balance upon the judicial branch.

\section{2) Public Policy Purpose}

Another purpose of the pardon power focuses not on obtaining justice for the person pardoned, but rather on the public-policy purposes of the government. For instance, James Wilson argued during the Convention that "pardon before conviction might be necessary in order to obtain the testimony of accomplices".

Pardons have also been used for the broader public policy purpose of ensuring

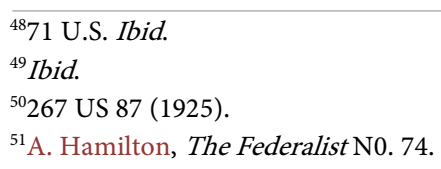


peace and tranquility in the case of uprisings and to bring peace after internal conflicts. Hamilton ${ }^{52}$ asserted that "in seasons of insurrection or rebellion there are often critical moments when a well-timed offer of pardon to the insurgents or rebels may restore the tranquility of the Commonwealth; and which, if suffered to pass unimproved, it may never be possible afterwards to recall" ${ }^{53}$ Thus, after the American Civil War in the $19^{\text {th }}$ Century, Abraham Lincoln and his successor pardon most of the solders who fought for the confederacy.

\section{Power to Pardon in Other Jurisdictions}

The origin and application of the pardon power in different jurisdictions, relevant to this study, are examined in this section. Importantly, the nature and extent of restraints, if any, on the exercise of the pardon power are highlighted. The purpose is to determine what lessons could be learnt by Nigeria from the operation of the pardon power in these jurisdictions; and not for making any specific recommendation for improvement in those jurisdictions. The selected jurisdictions are, United Kingdom (UK) United States, India, Ireland, South Africa, Zambia and Uganda:

3) UK

It has already been pointed out that, the power of pardon which was historically vested in the British monarch, was an act of mercy, whereby, the king "forgiveth any crime, offence, punishment, execution, right, title, debt, or duty." At present, the monarch exercises the power on the advice of the Home Secretary, whose decision can, in some situations, be challenged by judicial review (Sebba, 1977). In $\boldsymbol{R} \boldsymbol{V}$ Secretary of State for the Home Department, ex parte Bentley, ${ }^{54}$ the Court held that the royal prerogative of pardon is a flexible power. Thus, the Home Secretary's discretion on the exercise of the prerogative of mercy is a wide discretion. Nevertheless, the Home Secretary's decision to pardon a prisoner is susceptible to judicial Review. Thus, it may be concluded that in the UK, judicial review of the power of pardon is extremely restricted in scope, because the British constitutional structure recognises the supremacy of Parliament and provides an altogether narrower scope for judicial review (Islam, 2012).

\section{4) United States}

The presidential power to pardon was derived from the royal English prerogative of kings which dated from the Norman invasion. ${ }^{55}$ The power is now enshrined in Article 11, section 2, Clause 1, of the US Constitution, which provides that the President "shall have power to grant reprieves and pardons for offences against the United States, except in cases of impeachment". A President or Governor may grant a full (unconditional) pardon or a conditional pardon. The full

${ }^{52} 71$ Ibid.

${ }^{53}$ See generally, J. Pfiffner, “The President's Broad Power to Pardon and Commute", available at http://www.heritage.org/report/thepresident's-broad-power-to-pardon. Accessed 5/11/2017. ${ }^{54}$ (1994) QB 349.

${ }^{55}$ Pfiffner, Op. Cit. See also W.F. Duker, “The President's Power to Pardon: A Constitutional History”, (1977) 19 William \& Mary L. Rev. 475, available at http://scholarship.law.wn.edu/wmlr/vol.18/iss3/3. Accessed 15/2/2018. 
or unconditional pardon entails that a recipient of a pardon may regain the right to vote and to hold various positions of public trust. On the other hand, a conditional pardon is said to impose a condition on the offender before it becomes effective.

All requests for executive clemency for federal offences are directed to the pardon Attorney for investigation and review. ${ }^{56}$ The pardon Attorney prepares the Department's recommendation to the President for final disposition of each application. ${ }^{57}$ However, it has been noted that the most controversial cases of pardon usually bypass the normal review process. Among such pardons in recent times, include President Donald Trump's, pardon of Joe Apaio, a former Sheriff of Maricopa Country, Arizona, found guilty in July 2017 of criminal contempt; and President Bush's commutation of the prison sentence imposed on White House Aide, Lewis Libby in 2007. Libby, Vice President Chaney's former Chief of Staff had been convicted of perjury and obstruction of justice in connection with the leak of CIA agent Valerie Wilson's identity; and sentenced to 30 months in prison. Commenting of the swiftness of Libby's pardon and non-compliance with established procedure, Margaret Love, ${ }^{58}$ stated as follows: “The President acted just a few hours after the Court of Appeal rejected Libby's request to remain free on bail while pursuing his appeal, by-passing entirely the justice departments clemency review process".

In the same manner, President Gerald Ford pardoned ex-President Richard Nixon following the widely publicised Watergate scandal and Nixon's resignation. President George H.W. Bush pardoned six government officials prosecuted in connection with the Iran-contra investigation. The President justified his action by saying that all six were "patriots" with a long and distinguished record of service to the country who had been caught up in the criminalisation of policy differences. ${ }^{59}$ President Reagan pardoned two FBI officials convicted of authorising illegal "black bag jobs" whose cases were still on appeal.

Margaret Love ${ }^{60}$ confirmed that these presidential pardons did not follow the established Justice Department procedure for handling pardons, and were controversial. However, in the case of United States $v$ Klein, ${ }^{61}$ the US Supreme Court held that Congress and implicitly the judiciary could not interfere with the President's power to pardon.

5) India

In the Constitution of India, the power of presidential pardon is found in Ar-

${ }^{56}$ In 1898, President Mckinley signed the first federal clemency rules directing that all application for pardon or sentence commutation should be submitted to the justice Department's pardon Attorney for review.

${ }^{57}$ See "Office of the Pardon Attorney", available at http://www.justice.gov/pardon. Accessed 5/11/2017.

${ }^{58}$ Love, Op. Cit, at 1.

${ }^{59}$ See Proclamation 6518 (Dec. 24, 1991) available at http://jurist.law.pitt.edu/pardonsex5.htm. accessed 11/5/2017.

${ }^{60}$ See "Pardon Abuse-Not what the Founders had in mind available at http://shadowproof.com/2007/10/07/pardon-abuse-.Accessed 11/5/2017.

${ }^{61} 80$ US 128 (1871). 
ticle 72. It empowers the President to "grant pardons, reprieves, respites or remissions of punishment in all cases where the punishment is for an offence against any law to which the executive power of the Union extends". It is settled that the President shall exercise his pardon power in accordance with ministerial advice and not at his individual discretion. However, there are some grounds upon which the President shall exercise his pardon power. The grounds include the following: ${ }^{62}$

1) Interest of society and the convict.

2) The period of imprisonment undergone and the remaining period.

3) Seriousness and relative recentness of the offence.

4) The age of the prisoner and the reasonable expectation of his longevity.

5) The health of the prisoner.

6) Good prison record.

7) Post conviction conduct, character and reputation.

8) Remorse and atonement.

9) Deference to public opinion.

Though the circumstances and the criteria for exercise or non-exercise of pardon power may be of infinite variety, the principle is well settled and admits of no doubt or debate, namely, that the power of pardon should be exercised on public considerations alone. ${ }^{63}$ It has been judicially established that presidential pardon under Article 72 of the Indian Constitution is subject to judicial review on the grounds mentioned in the case of Maru Ram $\boldsymbol{v}$ Union of India. ${ }^{64}$ In that case, the court, while deciding on the validity of $433 \mathrm{~A}$ of the Code of Criminal Procedure, examined the power of pardon under Article 72 and observed as follows:

Pardon using this expression in the amplest connotation, ordains fair exercise, as we indicated above. Political vendetta or party favouritism cannot but be interlopers in this area. The order which is the product of extraneous or mala fide factors will vitiate the exercise ... For example, if the Chief Minister of State releases everyone in the prisons in his State on his birthday or because a son has been born to him, it will be an outrage on the Constitution to let such madness survive.

In the more recent case of Epuru Sudhakar \& Anor $v$ Govt of Andhra Pradesh \& Ors, ${ }^{65}$ the Supreme Court of India held that "Clemency is subject to judicial review and it cannot be dispensed as a privilege or act of grace". In that case, the Supreme Court quashed the decision of a State Governor, which had commuted the sentence of a convicted congress activist. 


\section{6) Ireland}

In Ireland, the power of pardon is nominally exercised by the President, who must act "on the advice" of the Cabinet. Thus, in practice, the decisions to pardon are made by the government of the day and the President has no discretion in the matter. The responsibility can also be vested in persons or bodies other than the President. The Irish Constitution states that, "The right of pardon and the power to commute or remit punishment imposed by any court exercising criminal jurisdiction are hereby vested in the President, but such power of commutation or remission may also be conferred by law on other authorities" ${ }^{66}$

\section{7) South Africa}

In South African, the concept of pardon is also traceable to the British system and is reflected in the South African Constitutions of 1961, 1983 Interim Constitution and the current 1996 Constitution. However, the Interim Constitution translated the royal prerogatives into statutory or enacted prerogatives. In this regard, the Constitutional court, in one of its certification judgments, stated that regardless of historical origins of the concept, the President derives this power not from antiquity but from the Constitution itself.

Under the present South African Constitution, 1996, the power of pardon is vested in the President by Article 84(2) (j), which provides that: "The President is responsible for... pardoning or reprieving offenders and remitting any fines, penalties or forfeitures".

The power under section 84(2) (j) of the Constitution of South Africa 1996 can be used to pardon an individual, ${ }^{67}$ or a group of people. ${ }^{68}$ In Hugo's case, President Mandela remitted the sentences of all mothers with children under the age of 12 who were imprisoned for having committed minor offences. In Albutt $^{69}$ and Chonco $^{70}$ President Mbeki pardoned certain people who would have been eligible for amnesty from the Truth and Reconciliation Commission, but who failed to apply for it. Parliament cannot restrict the President's power through legislation ${ }^{71}$ and the President cannot restrict it himself by agreement. ${ }^{72}$ While the power is broad, it is not unrestricted. The most significant restriction is that it must be exercised in a way that is consistent with the Constitution. ${ }^{73}$ Thus, the President cannot pardon in breach of the Bill of Rights and must act in good faith. A pardon in exchange for a bribe would be an example of one made in bad faith. The power must be exercised rationally. It must be rationally related

\footnotetext{
${ }^{66}$ Islam Constitution of Ireland, Art. 13.6.

${ }^{67}$ See President of South Africa v Hugo 1997(4) SA 1 Para 29.

${ }^{68}$ Hugo, Supra.

${ }^{69}$ Albutt v Centre for the Study of Violence and Reconciliation 2010(3) SA 293 (CC).

${ }^{70}$ Minister for Justice and Constitutional Development $v$ Chonco 2010(4) SA 82 (CC).

${ }^{71}$ President of the Republic of South Africa v South African Rug by Football Union 2000(1) SA 1(SARFU) para. 155.

${ }^{72}$ Ibid para. 159.

${ }^{73}$ Certification of the Constitution of the Republic of South Africa 1996(4) SA 744 (CC) para 116.

${ }^{74}$ See generally; Piet Olivier, "Crime and Punishment (and presidential pardons) Does the Constitution permit the pardoning of the corrupt?" Available at

http://hsf.org.za/resource-centre/hsf-briefs/crime-and-presidential-pardons. Accessed 15/2/2017.
} 
to a legitimate purpose. The President must exercise the power personally. ${ }^{74}$ In the case of President of the Republic of South Africa and others $v$ South African Rugby Football Union and Others (The SARFU case), the Constitutional Court held that the powers conferred upon the President by section 82(1) of the Interim Constitution; which are similar to those conferred by section 54(2) of the 1996 Constitution, are conferred on him as the Head of State rather than as the Head of the National Executive. Apart from item 9(2) of schedule 5 to the present South African Constitution, read with clause 1 of Annexure in schedule 6, which provides that until 30 April 1998 the President must consult the Executive Deputy Presidents before the exercise of certain powers including pardon, the Constitution does not oblige the President to consult any person before the exercise of the power of pardon ${ }^{75}$. The President is therefore solely responsible for the Head of State powers in section 84(2) of the Constitution. ${ }^{76}$

The reviewability of the President's power to pardon as evident in the Hugo's case $^{77}$ was upheld by section 239 of the 1995 Constitution. The section provides that the exercise of power or performance of a function in terms of the Constitution amounts to conduct of an organ of State and by the provisions of the Bill of Rights $^{78}$ all organs of State are bound together.

\section{8) Zambia}

Under the Constitution of Zambia, ${ }^{79}$ sections 44(2) (c) and 59 vest the power of pardon in the President. While section 44(2) (c) relates to the President's power to grant pardon or reprieve offenders, either conditionally or subject to such conditions as he may consider fit, section 59 relates to presidential prerogative of mercy by which he can grant to any person convicted of any offence a pardon, either free or subject to lawful conditions, or grant a respite, substitute a less sever punishment or remit any punishment imposed on any person for an offence. ${ }^{80}$ Section $44(6)$ of the Constitution further provides that, "in the exercise of any functions conferred upon him under section 44, the President shall, unless otherwise obliges, act in his own deliberate judgment and shall not be obliged to follow the advice tendered by any person or authority". In the exercise of the presidential pardon power under section 59 of the Constitution, section 60 provides for an Advisory Committee on Prerogative of Mercy consisting of persons appointed by the President. The President determines the procedure of the

\footnotetext{
${ }^{75}$ As the Interim Constitution did.

${ }^{76}$ Consequently, the President can exercise the power of the Head of State including power to pardon entirely on his or her own.

${ }^{77}$ The President of South Africa v Hugo (CUT II 196) SA I (18 April 1997) (Although that judgment concerned the Interim Constitution, it was highlighted there that in cases where the President pardons a single prisoner, it is difficult to conceive a constitutional attack being mounted against such exercise of presidential power. However, the Presidents is expected to exercise the powers in good faith. Where he abuses his powers or acts in bad faith, that court may be activated to intervene.

${ }^{78}$ Section $8(1)$ of the South African Bill of Rights.

${ }^{79}$ Constitution of Zambia, 1996.

${ }^{80}$ From the wordings of the provisions of section $44(2)$ (c) and section 59 of the Constitution of Zambia, the power to pardon under section 59, can only be exercised in favour of persons convicted of an offence; whereas, conviction is not a requirement under section 44(2) (c) of the Constitution.
} 
committee and presides at any of its meeting, if he is present. It is obvious that the President is not bound by the advice of this committee.

\section{9) Uganda}

The Constitution of Uganda ${ }^{81}$ provides for the establishment of an Advisory Committee on the Prerogative of Mercy, which shall consist of the Attorney General and six prominent citizens of the State appointed by the President. The President may on the advice of the Advisory Committee, grant a pardon to any person convicted of an offence, either free or subject to lawful conditions.

\section{Appraisal of Presidential Power to Pardon in Various Jurisdictions}

It is obvious that Presidents in various countries have applied the pardon power with unequal weight. Numerous cases of public officials charged with high trust violation of law, embezzlement of public funds who are shielded by the exercise of the power of pardon abound. At the same time men who have committed petty offences but with no money or influential politicians to speak for them, languish in prisons and are usually not considered for pardon.

The power to pardon vested in the executive under the Constitutions of many countries is broad and without limitations. Generally, there are no rules as to how the President should consider a case, what information he should seek or consider, what weight he should attach to the judicial decision except such as he may impose by himself. To this end, the power to pardon becomes highly susceptible to abuse.

In various jurisdictions, including the United States and Nigeria, the pardon power is virtually unchecked by formal constraints. There are no formal measures to limit or overturn the use of the power to pardon. However, in the United States, applications for pardon in respect of federal offences are usually sent to the Pardon Attorney, in the Department of Justice, for review and recommendation to the President. It has been shown in this paper that Presidents often bypass the review process and grant pardons in most of the controversial cases. In South Africa and India there are conventionally specified criteria that guide the grant of presidential pardon, which to some extent, serve as a check. Obviously, an unrestrained exercise of the power to pardon has continued in most jurisdictions with the attendant abuse of power by granting to the rich, influential and indeed undeserving convicts, while the poor, but deserving ones, are not considered for pardon.

Judicial review of the exercise of pardon power is allowed in South Africa and India but not in most other jurisdictions. Indeed, judicial review can be properly used to enforce textual limitations on clemency power. ${ }^{82}$ It can also serve the purpose of limiting the ability of executives to condition grants of pardon on the

${ }^{81}$ Constitution of the Federal Republic of Uganda, 1995, s. 121(1).

${ }^{82}$ D.T. Kobil, "Compelling Mercy: Judicial Review and the Clemency Power" (2012) 9, Journal or University of St. Thomas, Article 4. Impeachment or other sorts of political checks are alternative means of deterring unconstitutional pardon grants. 
relinquishment of fundamental constitutional rights. It is only appropriate for courts in some circumstances to review clemency practices that deprive applicants of equal protection or due process of law.

\section{Conclusion}

The power to grant pardon is of ancient origin and recognised today in almost every nation. It is capable of correcting the mistakes of the judiciary, particularly, where one may have been wrongly convicted or where the punishment was unduly excessive. However, in recent times, the pardon power has been abused as political and other extraneous factors tend to determine its application. It has also been seen as capricious and inaccessible by ordinary people. The usefulness of the power has seriously been dented by lack of control and checks in most jurisdictions, including Nigeria.

The pardoning power is the most sacred and difficult of all executive functions. Though it is regarded as a prerogative, based solely on presidential or executive discretion, there ought to be checks and guiding principles to avoid injustice in the quest for equity. By that, public interest shall be better served, reform of the prisoners more attained and welfare of the family and community advanced by a liberal but discrete use of the pardoning power. Ultimately, the ability of the President to use the pardon power fairly and dispassionately will, to a large extent, depend on his personal integrity and sense of responsibility. While the President should be allowed wide latitude in the exercise of his power of pardon, the prescription of some guidelines for granting pardon, as obtainable in India and South Africa, is also desirable. This, of course, cannot prevent the abuse of presidential pardon power, but it would go a long way in curbing the incidence of abuse. Indeed, the grant of pardon in all cases should be rational and aimed at serving some public policy purpose in order to justify the President's interference with the judicial determination of guilt and punishment. For Nigeria, in particular, it is recommended that the advice of the Council of State on the grant or refusal of pardon to applicants should be made binding on the President in all cases; instead of the current situation where such advice is only binding in respect of cases involving military officers and discretionary in respect of all others.

\section{References}

Agbedo, F. (2013). Presidential Pardon under the Constitution. The Nation. http://thenationaonline.net/presidential-pardon-under-the-constitution

Blackstone, W. (1769). Commentaries on the Laws of England (Ch. 31).

Coke, E. (1669). The Third Part of the Institutes of the Laws of England (4th ed.). London: W. Clarke and Sons.

Dicey, A. V. (1959). Introduction to the Study of the Law of the Constitution (10th ed.). London: Macmillan Education Ltd.

Duker, W. F. (1977). The President's Power to Pardon: A Constitutional History. William \& Mary Law Review, 475. http://scholarship.law.wn.edu/wmlr/vol18/iss3/3 
Ekwenze, S. A. M. (2018). Presidential Pardon and Prerogative of Mercy: A Necessary National Soothing Balm for Social Justice.

http://coou.eduing/nesources/presidential-pardon-and-prerogative-of-mercy

Garner, B. A. (Ed.) (2009). Black's Law Dictionary (9th ed.). St. Paul, MN: Western Publishing Co. Thomas Reuters.

Hamilton, A. (1788). The Federalist No. 74.

Hood-Philips, O., \& Jackson, (2001). Constitutional and Administrative Law. London: Sweet \& Maxwell.

Iluyomade, B. O., \& Eka, B. U. (1980). Cases and Materials on Administrative Law in Nigeria (pp. 1-2). Ile-Ife: University of Ife Press.

Islam, M. M. (2012). Judicially Reviewing the President's Prerogative of Mercy: A Comparative Study. Bangladesh Research Publications Journal, 7, 257-266.

Kobil, D. T. (2012). Compelling Mercy: Judicial Review and the Clemency Power. University of Saint Thomas Law Journal, 9, 698-729.

Locke, J. (1764). Second Treaties of Civil Government (Chapters 12-13).

Love, M. C. (2007). Reinventing the President's Pardon Power. Federal Sentencing Reporter, 20, 5-15. https://doi.org/10.1525/fsr.2007.20.1.5

Mpamugoh, V. A. (1988). Exercise of Prerogative of Mercy: Dr. Obi Okongwu's Pardon Visited. The Calabar Law Journal, 2, 45-46.

Nwabueze, B. O. (1964). Constitutional Law of the Nigerian Republic.

Nwabueze, B. O. (1982). The Presidential Constitution of Nigeria (pp. 144-145). London: C. Hurst \& Company.

Olarinde, E. S. Current Trends in Granting Pardon in United Kingdom, United States of America and Nigeria. http://www.academia.edu/10338732/CURRENT_TREND_IN_GRANTING_PARDON IN

Olivier, P. (2016). Crime and Punishment (and Presidential Pardons) Does the Constitution Permit the Pardoning of the Corrupt? http://hsf.org.za/resource-centre/hsf-briefs/crime-and-presidential-pardons

Pfiffner, J. (2007). The President's Broad Power to Pardon and Commute. http://www.heritage.org/report/thepresident's-broad-power-to-pardon

Sebba, L. (1977). Clemency in Perspective. In F. Landau, \& L. Sebba (Eds.), Criminology in Perspective: Essays in Honour of Israel Drapkin (pp. 225-228). Lexington: Mass Lexington Books. 